\title{
Combined immunological and histochemical analysis of skin and lymph node lesions in histiocytosis $\mathrm{X}$
}

\author{
JA THOMAS,* G JANOSSY,* M CHILOSI, $\dagger$ J PRITCHARD, $\ddagger$ JR PINCOTT§ \\ From the *Department of Immunology, Royal Free Hospital School of Medicine, London NW3, the \\ $\dagger$ Institute of Histopathology, University of Padua, Verona, Italy, and the Departments of $\ddagger$ Haematology and \\ Oncology §Pathology, Hospital for Sick Children, Great Ormond Street, London WCI
}

SUMMARY The immunological phenotype of the cells involved in skin and lymph node lesions from two cases of histiocytosis $\mathrm{X}(\mathrm{H}-\mathrm{X})$ were analysed by immunofluorescence techniques using combinations of heterologous and monoclonal antisera to Ia-like antigen and human cortical thymocyte (HTA-1) determinant. These cells were also characterised by a new technique using simultaneous immunofluorescence and enzyme histochemistry for acid phosphatase (ACPase). The major cell type in the lesions was found to express the same $\mathrm{Ia}^{+}, \mathrm{HTA}-1^{+}$phenotype as normal epidermal Langerhans' cells (LC) and was unreactive for ACPase. Additional cell types included Ia-, HTA-1- multinucleate giant cells and residual lymphoid populations These findings endorse previous concepts that $\mathrm{H}-\mathrm{X}$ is a proliferation of abnormal LC and emphasise the heterogeneous nature of the cells involved in the disease.

Histiocytosis $\mathrm{X}(\mathrm{H}-\mathrm{X})$ is a generic term encompassing a group of rare clinical disorders (Hand-SchüllerChristian syndrome, Letterer-Siwe disease and eosinophilic granuloma) which show similar histological features. The lesions in these diseases contain granulomatous infiltrates of histiocytic cells with abundant eosinophilic cytoplasm. ${ }^{1}$ There is now extensive evidence to show that these cells are morphologically and ultrastructurally similar to epidermal Langerhans' cells (LC). Both cell types contain ultrastructurally distinct cytoplasmic bodies of Birbeck granules ${ }^{2} \mathbf{3}$ and are histochemically active for adenosine triphosphatase (ATPase) (4-5 $^{4}$ and $\alpha$ napthyl acetate esterase (ANAE). ${ }^{4-6}$ In addition, LC weakly express surface Fc IgG and $\mathrm{C} 3$ receptors? and contain abundant amounts of Ia-like antigen. ${ }^{8}$ Recent immunological studies have revealed surface receptors for HTA-1 (human thymocyte antigen) on LC defined by monoclonal antibodies NA1/34 ${ }^{9}$ and OKT6.1011 The expression of HTA-1 and Ia-like antigen on LC provides an important new phenotype (HTA-1 ${ }^{+}, \mathrm{Ia}^{+}$) by which these cells may be identified in immunohistological analyses of normal and pathological tissues. It is possible to identify the phenotypic expression of different immunological markers on the same cell type using two colour immunofluorescence techniques. ${ }^{12}$

Accepted for publication 21 September 1981
In addition to routine histological staining procedures, enzyme histochemistry has been used for many years to identify further various cell types in histological preparations. Hitherto, immunological and histochemical techniques have been confined to separate tissue sections as the optimal tissue processing for each method was considered to be different and incompatible. In this study, combined immunological and histochemical markers have been used to identify the proliferating cells in cutaneous and lymph node lesions from two cases of histiocytosis X. The aims of the study were threefold. Combinations of heterologous and monoclonal antibodies to lymphoid and non-lymphoid cells were used in double-labelled immunofluorescence (IF) studies on frozen sections (i) to establish whether there is a phenotypic relation between $\mathrm{HTA}-1^{+}, \mathrm{Ia}^{+} \mathrm{LC}$ and $\mathrm{H}-\mathrm{X}$ cells, (ii) to characterise the relation between $\mathrm{H}-\mathrm{X}$ cells and other cell types and (iii) to compare the histochemical characteristics of different cells with their immunological phenotype.

\section{Material'and methods}

\section{TISSUE PREPARATION}

A portion of each tissue biopsy (skin from case 1; lymph node from case 2) was processed for routine histology (haematoxylin and eosin), by $10 \%$ formalin 
fixation, and paraffin wax embedding. The other portions to be used in the immunological and histochemical studies were snap-frozen in isopentane (2-methyl-butane: BDH) and liquid nitrogen and stored at $-70^{\circ} \mathrm{C}$. Cryostat sections $(6 \mu \mathrm{m}$ and $10 \mu \mathrm{m})$ were mounted on to clean glass slides, air-dried for $12 \mathrm{~h}$ at room temperature $\left(20^{\circ} \mathrm{C}\right)$ before fixation in cold ethanol $\left(4^{\circ} \mathrm{C}\right)$ for $3 \mathrm{~min}$. Unfixed cryostat sections were also successfully stored at $-20^{\circ} \mathrm{C}$ before fixation.

\section{ANTISERA}

The panel of heterologous and monoclonal antisera are shown in Table 1 . The specificities of these reagents have been previously characterised in cell suspension and frozen sections of normal ${ }^{12} 13$ and pathological ${ }^{12}$ tissues. Combinations of indirectly labelled heterologous antisera to Ia-like antigen (chicken (C) anti-Ia), human $\mathrm{T}$ leucocyte antigen (rabbit (R) anti-HuTLA) and directly labelled antisera to human immunoglobulin subclasses were used to identify B $\left(\mathrm{Ia}^{+}, \mathrm{Ig}^{+}\right)$and $\mathrm{T}\left(\mathrm{HuTLA}^{+}, \mathrm{Ig}^{-}\right)$lymphocytes. Cells expressing receptors for HTA-1 determinant and Ia-like antigen were demonstrated by monoclonal antibodies OKT6 or NA1/34 in combination with $\mathbf{C}$ antiserum to Ia-like antigen. The histochemical staining reaction for acid phosphatase (ACPase) was used simultaneously with fluorescent labelled antisera to HTA-1 or Ia-like antigen.

\section{IMMUNOFLUORESCENT TECHNIQUES}

Direct and indirect IF techniques were used on $6 \mu \mathrm{m}$ cryostat sections. Applications of 5-10 $\mu \mathrm{l}$ of appropriately diluted primary antisera were made to moist sections then incubated in a damp chamber at $20^{\circ} \mathrm{C}$ for $30 \mathrm{~min}$. Excess antibody was removed by washing in phosphate-buffered saline (PBS) $\mathrm{pH} 7.6$ at $20^{\circ} \mathrm{C}$ for $10 \mathrm{~min}$. In the indirect IF test, species- specific rhodamine (tetramethyl rhodamine-isothiocyanate: TRITC) or fluorescein (fluorescein-isothiocyanate: FITC) labelled second layer reagents were applied to the sections for a further $30 \mathrm{~min}$. After final rinsing in PBS $\mathrm{pH} 7 \cdot 6$, the sections were mounted in $1 \%$ formol glycerol under a coverslip and examined with a $\times 40$ oil objective on a Zeiss 14 epifluorescence IV/Z microscope. Two distinctly labelled cell populations could be examined simultaneously using a selective (red/green) filter attachment.

\section{HISTOCHEMICAL TECHNIQUES}

Enzyme histochemistry was performed on $10 \mu \mathrm{m}$ cryostat sections prefixed in cold $\left(4^{\circ} \mathrm{C}\right)$ calcium formalin for $3 \mathrm{~min}$. Modifications of standard histochemical methods described by Chilosi et al ${ }^{15}$ were used to demonstrate activity for ACPase, ANAE, ATPase and tartrate-resistant acid phosphatase (TRAP).

\section{COMBINED IMMUNOFLUORESCENCE AND} HISTOCHEMICAL TECHNIQUES

Ethanol-fixed $\left(4^{\circ} \mathrm{C}\right) 6 \mu \mathrm{m}$ cryostat sections were initially stained in the indirect IF test with TRITClabelled C-anti-Ia-like antigen or monoclonal antibody to HTA-1 determinant (OKT6 or NA1/34). After the final rinse in PBS pH 7.6, the sections were immediately processed for the ACPase reaction using the modified Gomori metal salt procedure. ${ }^{1516}$ The IF sections were briefly (60 s) postfixed in $10 \%$ formalin, rinsed in distilled water then immersed in freshly filtered incubation medium* at $37^{\circ} \mathrm{C}$ for $60 \mathrm{~min}$. After two short washes in distilled water,

*0.1 M acetate buffer pH $5 ; 0.24 \%$ lead nitrate (Sigma); $3 \%$ sodium $\beta$ glycerosphosphate (Sigma). The medium was incubated at $37^{\circ} \mathrm{C}$ until complete precipitation of lead phosphate (6-24 h), cooled and filtered before use.

Table 1 Immunological reagents used in the direct and indirect IF analysis of cryostat sections

\begin{tabular}{|c|c|c|c|}
\hline First layer antibody* & Second layer antibody* & Reactivity pattern & Reference \\
\hline Chicken (C) anti-Ia-like antigen (1/80) & $\begin{array}{l}\text { Sheep anti-C-IgG }\left(\mathrm{Fab}_{2}\right) \\
\text { TRITC }(1 / 20)\end{array}$ & \multirow{3}{*}{$\begin{array}{l}\text { + + IDR cells, LC "veiled" } \\
\text { cells; + B cells; } \pm \text { myeloblasts } \\
\text { + thymocytes; peripheral T } \\
\text { cells, Thy-ALL blasts } \\
\text { + B cells, plasma cells }\end{array}$} & 12,13 \\
\hline $\begin{array}{l}\text { Rabbit (R) antihuman T leucocyte antigen } \\
\text { (HuTLA) }(1 / 20)\end{array}$ & $\begin{array}{l}\text { Goat (G) anti-R-IgG }\left(\mathrm{Fab}_{2}\right) \\
\text { FITC }(1 / 10)\end{array}$ & & 12,14 \\
\hline $\begin{array}{l}\text { FITC/TRITC conjugated antisera to whole } \\
\text { human Ig, IgM, IgD, IgG, } \mathrm{k}, \lambda \text { raised in goat } \\
\text { and burro } \\
\text { Mouse (M) monoclonal antibodies to human } \\
\text { thymocyte antigen HTA-1 }\end{array}$ & None & & 12 \\
\hline $\mathrm{NA} 1 / 34 \dagger$ & $\begin{array}{l}\text { G-anti-M-IgG-FITC }(1 / 10) \\
\text { G-anti-M-IgG }{ }_{1} \text {-TRITC }(1 / 10)\end{array}$ & \multirow{2}{*}{$\begin{array}{l}+ \text { cortical thymocytes }(90 \%) \\
- \text { medullary thymocytes }(5 \%)\end{array}$} & \multirow{2}{*}{$\begin{array}{l}9 \\
9,10,11\end{array}$} \\
\hline OKT6\$(1/10) & G-anti-M-IgG-FITC (1/10) & & \\
\hline
\end{tabular}

*Dilutions of antisera shown in brackets.

†Culture supernatant.

$\ddagger$ Ascitic fluid, 
the enzyme reaction was developed in $0.5 \%$ yellow ammonium sulphide (Sigma) for 2 min. The sections were rinsed finally in distilled water and mounted under a coverslip in $1 \%$ formol glycerol. Both the brown enzyme reaction product and TRITC-labelled antibodies could be easily examined under the fluorescence microscope using phase contrast and the appropriate (green) fluorescence filter channel.

Precautions were taken to ensure that the same enzyme reaction patterns were obtained in the combnied IF/enzyme tests as were demonstrated on sections which had been treated separately for IF or ACPase activity. Separate sections were stained for IF followed by ACPase localisation using either the pararosaniline ${ }^{16}$ or lead salt methods. Photographs of marked areas on the slide were taken after each procedure which were later superimposed to show identical areas of ACPase activity.

\section{PATIENTS}

\section{Case 1}

An 8-year-old boy presented in April 1980 with polydipsia and polyuria following a short influenzalike illness. Diabetes insipidus was diagnosed and he was treated with 1-diamino-8-D-arginine vasopressin (DDAVP). Five months later in September 1980, he developed severe breathlessness, weight loss and general lassitude. He was readmitted to hospital and on examination he was noted to have generalised areas of depigmentation (face, axillae, trunk and knees) as well as a papular eruption over the back. There was no lymphadenopathy or hepatosplenomegaly. Chest $x$-ray revealed a right pneumothorax and reticular changes in both lungs. No bone lesions were apparent on skeletal survey. The diagnosis of histiocytosis $\mathrm{X}$ was confirmed by skin biopsy and a right pleurectomy was performed. Postoperativeiy the child was treated with vinblastine and prednisolone and his condition markedly improved. At the latest follow-up (July 1981) the patient was well and continues on a modified regimen of vinblastine, and DDAVP to control the diabetes insipidus.

\section{Case 2}

A 6-month-old baby boy of Turkish Cypriot origin presented in March 1980 with failure to thrive, swellings behind the ears and apparent bone pain. On examination he had marked bilateral lymphadenopathy (cervical, parotid, submandibular, postauricular) and hepatosplenomegaly. In addition there was a petechial lesion on the left foot and papular lesions over the scalp. An $x$-ray examination showed multiple lytic areas throughout the skeleton (skull, femora, tibulae, humeri, lumbar vertebrae, ribs) as well as a large anteromediastinal shadow. There were no radiological lung changes. Excision biopsy of a left upper cervical lymph node showed the histological features consistent with histiocytosis $\mathrm{X}$. Treatment with vinblastine, prednisolone and antibiotics was followed by a rapid and marked clinical improvement. The lymphadenopathy, mediastinal mass and skeletal lesions resolved within three months of starting therapy. At 12 month follow-up, having continued on an intermittent regimen of vinblastine and steroids, the patient was well and developing normally.

\section{Results}

\section{HISTOLOGICAL PREPARATIONS}

(HAEMATOXYLIN AND EOSIN)

In case 1, the skin (Fig. 1a) showed marked narrowing of the epidermis with focal areas of large, round cells containing eccentric nuclei infiltrating the dermis and epidermis. These cells were accompanied by scanty numbers of small lymphocytes. In case 2 , the normal lymph node (Fig. 1b) architecture was virtually replaced by a profuse, mixed cell infiltrate consisting of irregular histiocytic cells with abundant eosinophilic cytoplasm, moderate numbers of plasma cells, lymphocytes and occasional eosinophils. The histiocytic cells showed wide morphological variation from bizarre multinucleate giant cells (containing from 6 to 12 nuclei) to smaller, irregular mononuclear forms with vesicular and folded nuclei. Small aggregates of residual lymphocytes were clearly present in the tissue apparently compressed by the abnormally proliferating cell population. Mitotic figures were occasionally recognised in both biopsies but these were too infrequent to substantiate a malignant process.

DEMONSTRATION OF IF AND HISTOCHEMICAL MARKERS ON CELL POPULATIONS IN H-X SKIN (CASE 1)

\section{Immunological analysis}

The dermal infiltrate of large, round cells showed strong reactivity for Ia-like antigen (Fig. 2a). These cells were situated in the upper dermis particularly along the dermoepidermal border. Scanty numbers of smaller $\mathrm{Ia}^{+}$round cells were present in the epidermis. In addition to the $\mathrm{Ia}^{+}$round cell population, there were occasional large, $\mathrm{Ia}^{+}$irregular cells in the dermis.

Using monoclonal antibodies OKT6 or NA1/34 (both detecting HTA/1 antigen) in combination with $\mathrm{C}$-anti-Ia-like antigen, all the $\mathrm{Ia}^{+}$epidermal cells and the majority $(>70 \%)$ of the $\mathrm{Ia}^{+}$dermal round cells expressed the HTA-1 determinant (Fig. 2b). Conspicuous numbers of $\mathrm{HTA}-1^{+}, \mathrm{Ia}^{+}$round cells were 


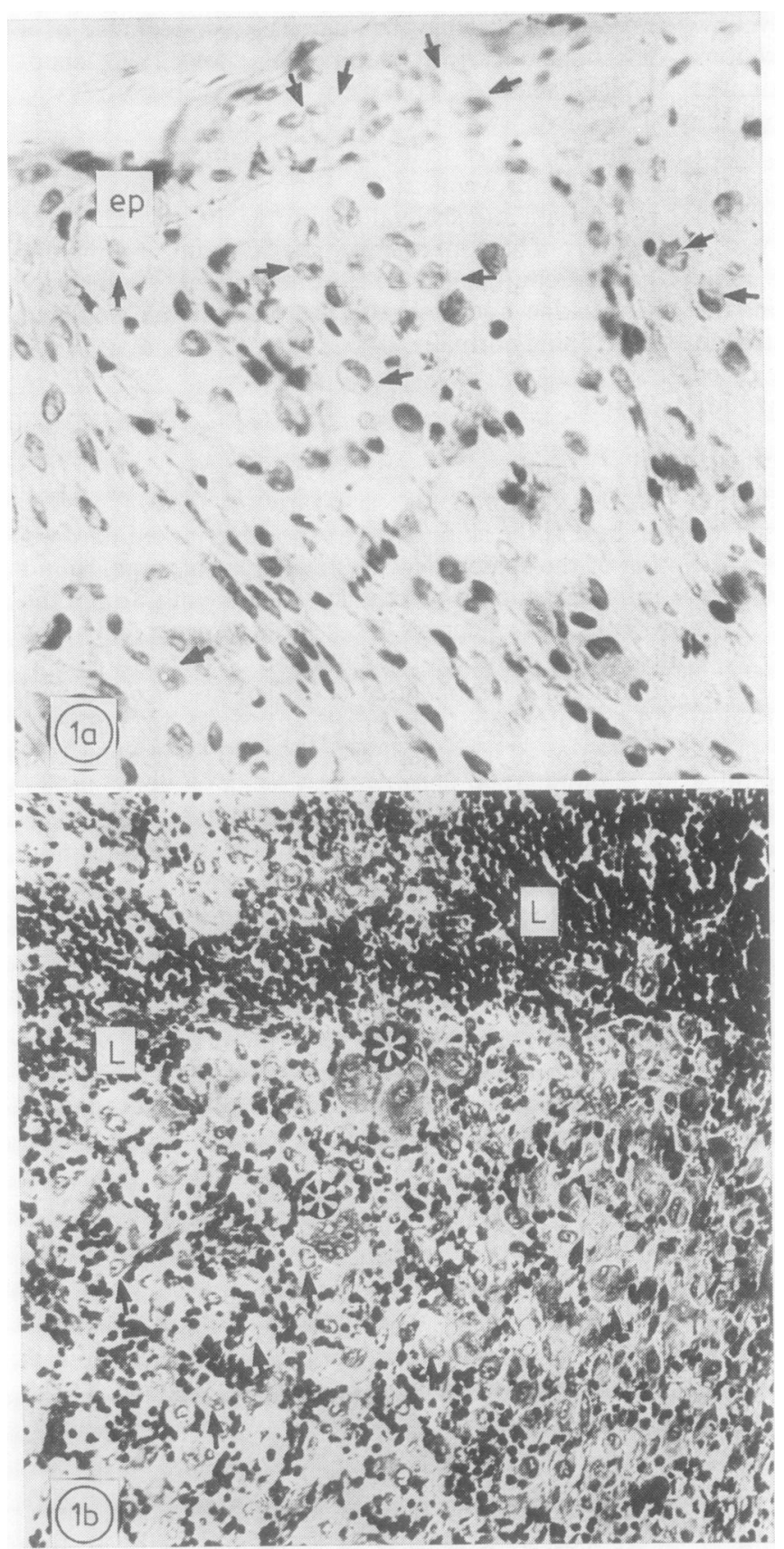

Fig. 1 Histiocytosis $X$ (Haematoxylin and eosin paraffin wax sections). (a) Skin case I: focal infiltrate of large round cells in the dermis and epidermis (arrows) $\times 480$.

(b) Lymph node case 2: diffuse infiltrate of mixed cell types replaces the normal lymph nodes architecture. The main cell type consists of large cells with eosinophilic cytoplasm (arrows) and multinucleate giant cells (asterisks). Other cells include residual lymphoid aggregates $(L)$ $\times 480$. present at the dermoepidermal border. Not all the cells in the infiltrate, however, expressed the HTA-1 ${ }^{+}$, $\mathrm{Ia}^{+}$phenotype. The large, dermal irregular cells were $\mathrm{Ia}^{+}$but HTA-1- Small numbers of HTA-1 ${ }^{+}, \mathrm{Ia}^{-}$ round mononuclear cells were also observed. These cells were smaller than either of the $\mathrm{HTA}-1^{+}, \mathrm{Ia}^{+}$and $\mathrm{Ia}^{+}$, HTA-1- cell types but were not morphologically or immunologically identifiable as $\mathrm{T}$ lymphoblasts. None of the cells in the skin reacted with antiimmunoglobulin reagents and virtually no $T$ 

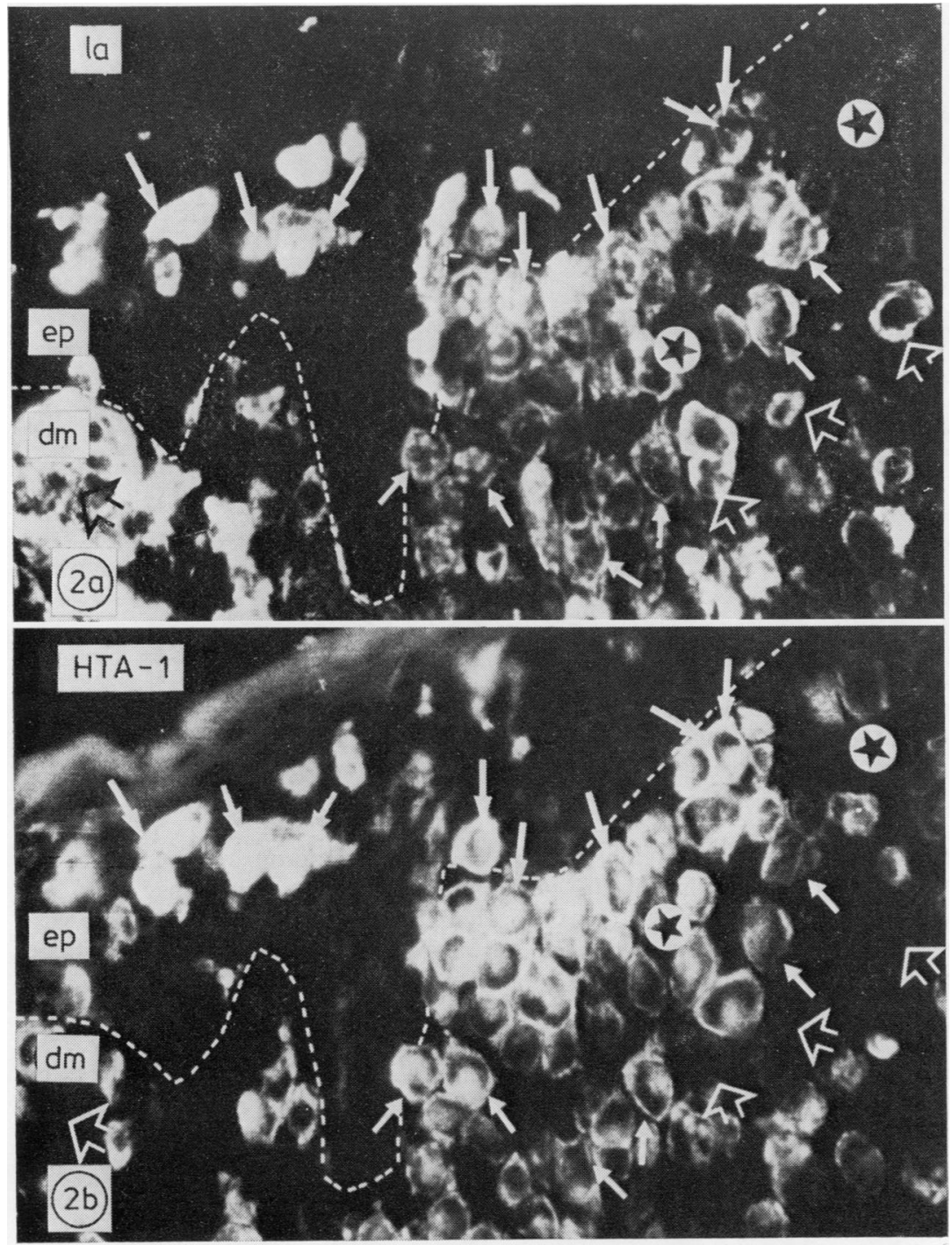

Fig. 2 Histiocytosis $X$ (cryostat section). Skin (case 1) stained with (a) C-antiIa-like antigen (TRITC) in combination with $(b)$ monoclonal antibody to HTA-1 determinant (OKT6-FITC). Numerous $\mathrm{Ia}^{+}, \mathrm{HTA}-\mathrm{I}^{+}$round type I cells (arrows) are present in the dermis, along the dermoepidermal border and in the epidermis. Ia ${ }^{+}, \mathrm{HTA}^{-\mathrm{I}^{-}}$ irregular type II cells (big arrows) are situated in the dermis as well as occasional Ia $a^{-}$, HTA-1+ mononuclear cells (star).

$\left(\mathrm{HuTLA}^{+}\right)$lymphocytes were identified in the frozen sections.

\section{Histochemical analysis}

The round cell infiltrate in the dermis and epidermis showed distinct membrane localisation of ATPase (Fig. 3a) but demonstrated weak cytoplasmic reactivity for ANAE (Fig. 3b) and ACPase. These ATPase $^{+}, \mathrm{ANAE}^{ \pm}, \mathrm{ACPase}^{ \pm}$round cells were unreactive with TRAP. By contrast, the infrequent $\mathrm{Ia}^{+}$irregular cells showed absent or weak localisation
(Fig. 3b), ACPase and granular, cytoplasmic TRAP ${ }^{+}$ activity.

DEMONSTRATION OF IF AND HISTOCHEMICAL MARKERS ON CELL POPULATIONS IN H-X LYMPH NODE (CASE 2)

Immunological analysis

A wide variety of cells expressed variable amounts of Ia-like antigen. Four main cell types could be identified on the basis of Ia-like antigen expression (Fig. 4a-d and Table 2). 

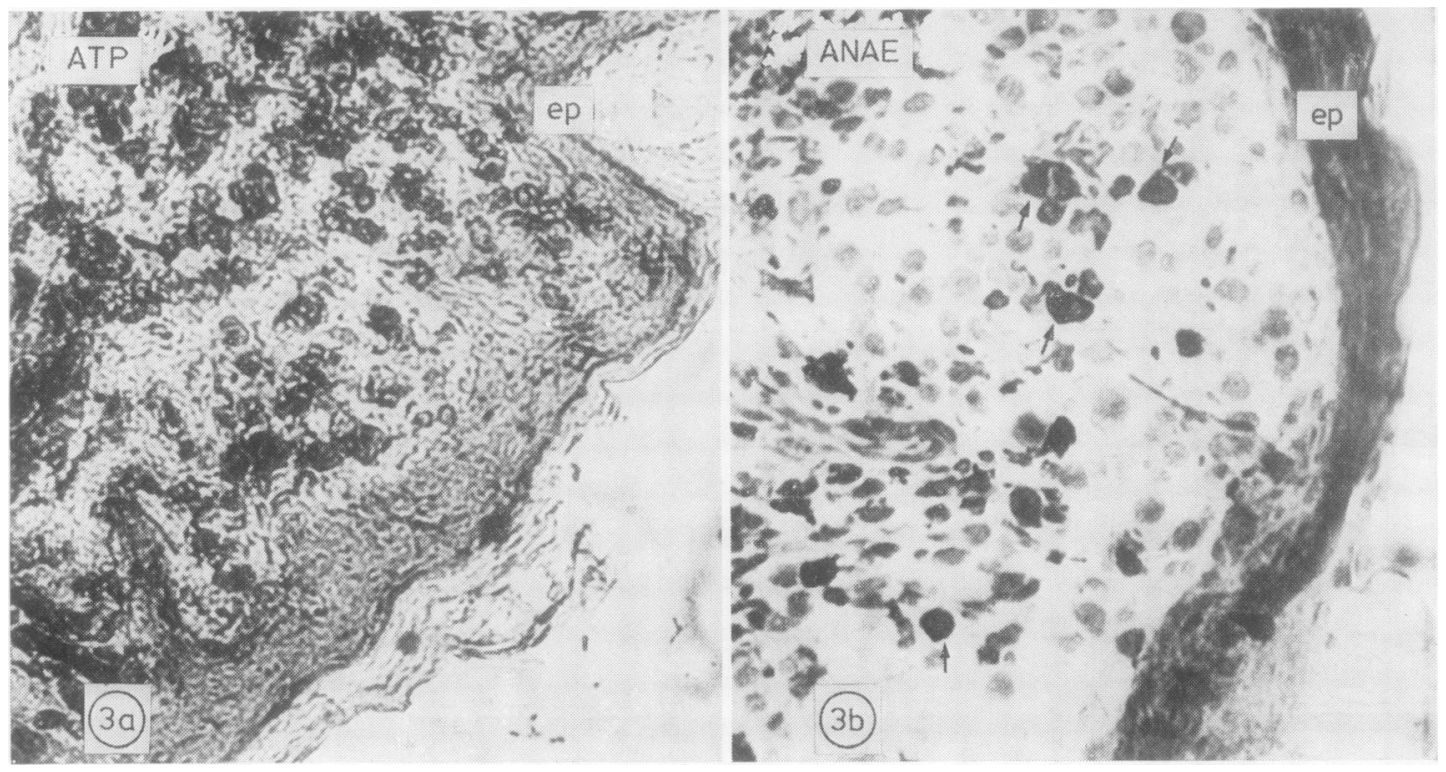

Fig. 3 Histiocytosis $X$ (cryostat section). Skin case 1: enzyme histochemical demonstration of (a) ATPase and (b) ANAE. (a) Most cells in the dermis and epidermis show strong ATPase activity and (b) weak ANAE activity although a few strongly ANAE ${ }^{+}$irregular cells (arrows) are scattered throughout the dermis.

(i) The majority of the infiltrating cell population consisted of round or asymmetrical large cells expressing moderate amounts of Ia-like antigen which appeared as a fine, granular staining pattern (Fig. 4a). On phase contrast microscopy, these cells were agranular and sometimes contained one or two characteristically folded nuclei.

(ii) Diffuse Ia-like antigen was present on a smaller population of cells with distinct irregular or stellate outlines produced by long processes (Fig. 4a).

(iii) In contrast to these two cell types, the bizarre multinucleate giant cells were conspicuous by their total absence or very weak expression of Ia-like antigen. The morphology of these cells could be identified on phase contrast microscopy and were distinguished as "black holes" in the fluorescent tissue preparations (Fig. 4c).

(iv) Collections of membrane $\mathrm{Ia}^{+}$small mononuclear lymphocytes constituted the fourth main cell type. These were surface membrane immunoglobulin $\left(\mathrm{SMIg}^{+}\right) \mathrm{B}$ cells (Fig. 4a).

When the sections were stained for HTA-1 determinant (Fig. 4b, d) prominent clusters of large $\mathrm{Ia}^{+}, \mathrm{HTA}-1^{+}$round or asymmetrical cells (type I) were observed throughout the tissue. These $\mathrm{Ia}^{+}$, HTA-1 ${ }^{+}$cells contrasted with large irregular $\mathrm{Ia}^{+}$, HTA-1 ${ }^{-}$cells (type II) and with confluent and scattered areas of $\mathrm{Ia}^{-}$, HTA-1- giant cells (type III). Cells with the Ia-, HTA-1+ phenotype were occasion- ally observed but these were much less conspicuous in the lymph node than in the skin biopsy. Very few $\mathrm{T}\left(\mathrm{HuTLA}^{+}\right)$lymphocytes were identified. These were scattered throughout the tissue and constituted $<2 \%$ of the total cell population.

As immunofluorescence for Ia-like and HTA-1 antigens could be combined with ACPase, the foregoing main cell types were also classified by enzyme histochemistry (Fig. 5a, b and Table 2). None of the round or asymmetrical $\mathrm{Ia}^{+}, \mathrm{HTA}-1^{+}$cells (type I) exhibited strong ACPase activity. The irregular $\mathrm{Ia}^{+}$, HTA-1- cells (type II) showed focal areas of moderate ACPase deposition (Fig. 5a, b insets) and the majority of $\mathrm{Ia}^{-}$, HTA-1 ${ }^{-}$multinucleate giant cells (type III) were strongly $\mathrm{ACPase}^{+}$. A few $\mathrm{ACPase}^{+}$giant cells however showed weak expression of Ia-like antigen(HTA-1-; Fig. 5a, b insets).

A further cell type was revealed by combined IF and histochemical analysis. Low numbers of small round $\mathrm{Ia}^{+}$, HTA-1- mononuclear cells contained prominent cytoplasmic ACPase ${ }^{+}$"dots" or granules. These cells were morphologically different from the $\mathrm{Ia}^{+}, \mathrm{HTA}^{-1}{ }^{-}$(type II) cells which were much more prominent in the tissue.

\section{Histochemical analysis}

Multinucleate giant cells exhibited strong or moderate ACPase and ANAE activity. The large round cells with characteristically folded nuclei were 


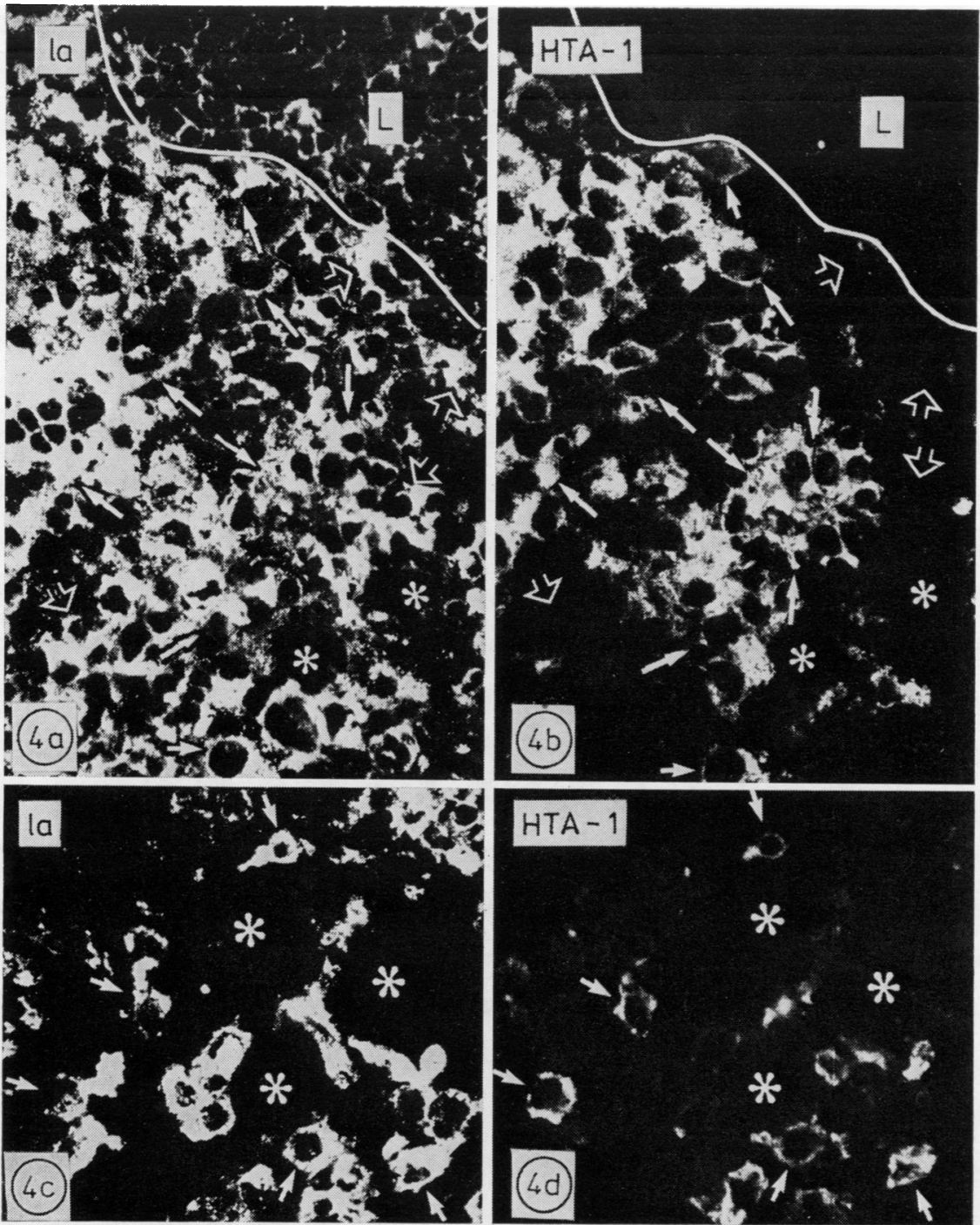

Fig. 4 Histiocytosis $X$ (cryostat section). Lymph node (case 2) stained with combinations of (a)-(c) C-anti-Ia-like antigen (TRITC) and (b)-(d) monoclonal antibody to HTA-1 determinant (OKT6-FITC). (a), (b). In most areas the cell infiltrate consists of dense clusters of $\mathrm{Ia}^{+}$, HTA-1+ round type I cells (arrows) with a few Ia+, HTA-1- irregular type II cells (big arrows) and Ia-, HTA-1- multinucleate giant type III cells (asterisk). Residual lymphoid areas $(L)$ contain membrane Ia+ $\left(H T A-1^{-}\right)$B cells. $(c),(d)$. Other areas of the same tissue contain prominent numbers of Ia-, HTA-1- multinucleate giant type III cells (asterisk) and scanty $\mathrm{Ia}^{+}, \mathrm{HTA}-\mathrm{I}^{+}$type I cells (arrows).

generally unreactive or weakly reactive for ANAE, ACPase and ATPase. Additional ANAE + , ACPase ${ }^{+}$ cell types included irregular and round mononuclear cells with either cytoplasmic granules or diffuse deposition of enzyme reaction products. Only a small proportion of multinucleate giant cells $(30 \%)$ showed ATPase and TRAP activity.

\section{Discussion}

The two cases presented in this study showed typical (though different) clinical features associated with histiocytosis $\mathrm{X}$. Histologically characteristic lesions in the skin and lymph node biopsies confirmed the diagnosis in both patients. In the skin, the 
Table 2 Immunological and histochemical characteristics of the major cell types in $H$-X lymph node (case 2)

\begin{tabular}{|c|c|c|c|c|c|c|c|}
\hline Cell types & Ia-like antigen & HTA-1 antigen & $S M I g^{*}$ & ACPase & ATPase & $A N A E$ & $T R A P$ \\
\hline $\begin{array}{l}\text { Round/asymmetrical cells } \\
\text { (type I) }\end{array}$ & $\begin{array}{l}+ \\
\text { (granular) }\end{array}$ & + & - & - \pm & \pm & - \pm & - \\
\hline $\begin{array}{l}\text { Irregular/stellate cells } \\
\text { (type II) }\end{array}$ & $\stackrel{+}{\text { (diffuse) }}$ & - & - & $\stackrel{+}{(\text { focal })}$ & + & \pm+ & - \\
\hline $\begin{array}{l}\text { Multinucleate giant cells } \\
\text { (type III) }\end{array}$ & - \pm & - & - & ++++ & $\pm+t$ & $+t+$ & $+\dagger$ \\
\hline $\begin{array}{l}\text { Residual B lymphocytes } \\
\text { (type IV) }\end{array}$ & + & - & + & - & + & - & - \\
\hline
\end{tabular}

*Surface membrane immunoglobulin.

+ATPase and TRAP demonstrated in $30 \%$ multinucleate giant cells.

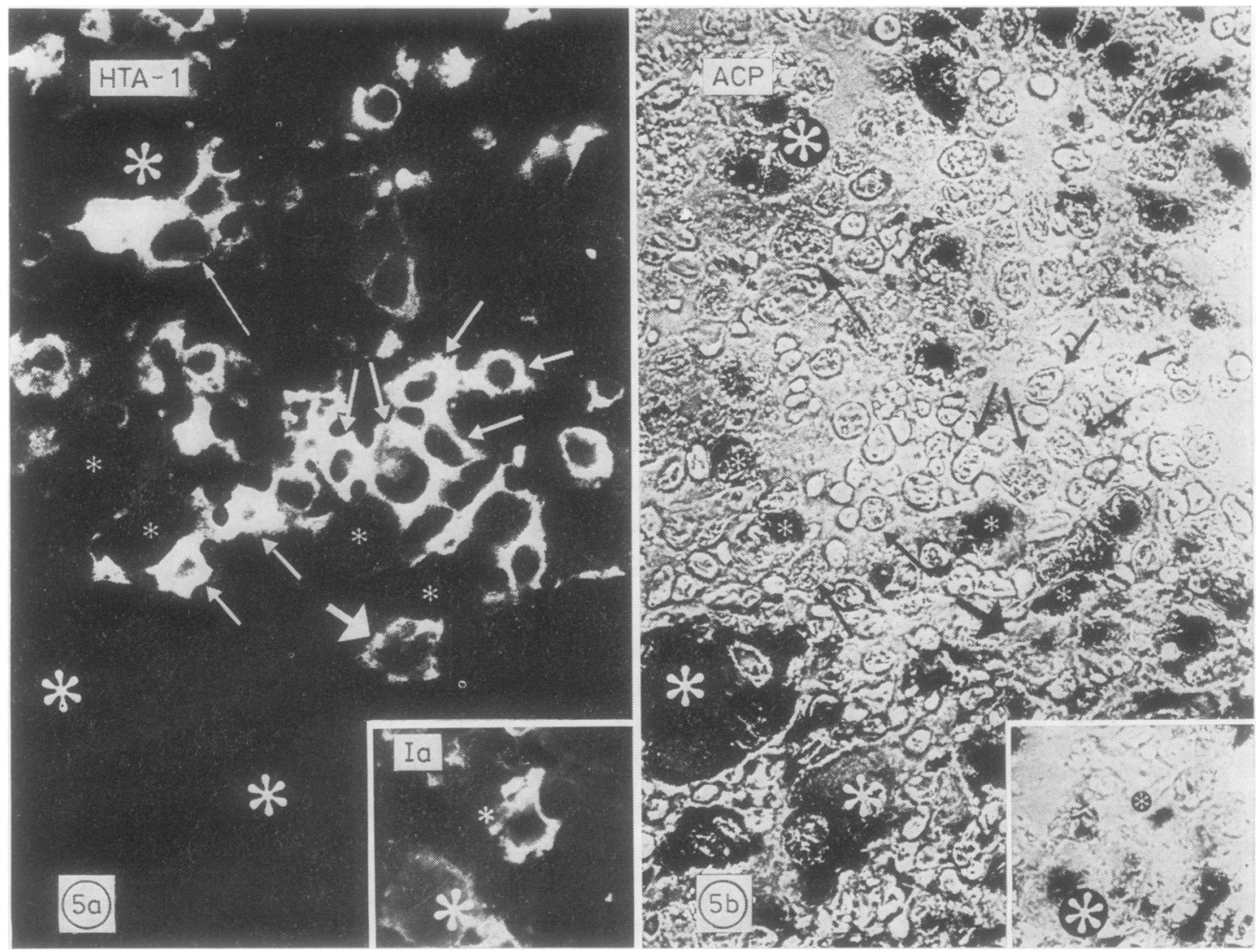

Fig. 5 Histiocytosis $X$ (cryostat section). Lymph node case 2: combined histochemical and immunofluorescence analysis with (a) monoclonal antibody to HTA-1 antigen (NA1/34-TRITC), (inset a) C-anti-Ia-like antigen (TRITC) and (b) ACPase. A cluster of HTA-I+ $\left(\right.$ Ia $\left.{ }^{+}\right)$round (type I) cells do not exhibit ACPase activity (arrows). Intense ACPase reactions are present in large and medium sized HTA-1-(Ia-) giant type III cells (asterisk). Insets (a), (b) show a single Ia $\mathrm{a}^{+},\left(\mathrm{HTA}-\mathrm{I}^{-}\right)$irregular type II cell containing localised ACPase ${ }^{+}$reaction products (asterisk). A giant cell with weak expression of Ia-like antigen and moderate ACPase activity is also identified (big asterisk).

relatively homogeneous population of large round cells with kidney shaped nuclei were similar in morphology and distribution to previous descriptions of $\mathrm{H}-\mathrm{X}$ cell infiltrates. ${ }^{517} 18$
The main feature of this study is the demonstration that many of the cells in the skin and lymph node express the same $\mathrm{Ia}^{+}, \mathrm{HTA}-1^{+}$phenotype as normal epidermal LC. This finding demonstrated by com- 
bined IF analysis confirms previous evidence that $\mathrm{H}-\mathrm{X}$ cells may be related to LC. Abundant amounts of Ia-like antigens have been demonstrated on normal LC by IF $^{810}$ and immunoelectronmicroscopic studies. ${ }^{19}$ Recently, cortical thymocyte antigen HTA-1 has also been demonstrated on LC defined by monoclonal antibody OKT6.10 11 It has been shown that both OKT6 and NA1/34 monoclonal antibodies react with HTA-1 antigen although with different epitopes on the same molecule. ${ }^{10}$ The fact that these two independently produced monoclonal antibodies react with LC indicates that this is not a chance cross-reaction between single epitopes on two unrelated molecules but rather that these cells carry at least part of the same HTA-1 molecule. Thus the $\mathrm{Ia}^{+}, \mathrm{HTA}-1^{+}$phenotype provides an important new marker for LC in addition to the well established morphological criteria of ultrastructurally defined Birbeck granules ${ }^{2}$ and histochemical demonstration of ATPase. 45

Most of the proliferating cells in the skin expressed the $\mathrm{Ia}^{+}$, HTA- $1^{+}$phenotype although a few irregular forms exhibited Ia-like antigen alone. It was interesting to observe the presence of many $\mathrm{Ia}^{+}$, HTA- $1^{+}$cells in the dermis. This contrasts with a variety of dermatological conditions such as mycosis fungoides (MF), lichen planus (LP) and graft-versushost disease (GvHD) in which the dermis is infiltrated by numerous strongly $\mathrm{Ia}^{+}$but $\mathrm{HTA}-1^{-}$ irregular cells. The $\mathrm{Ia}^{+}, \mathrm{HTA}-1^{+}$cells in these disorders (MF, LP, GvHD) are primarily restricted to the epidermis and $\mathrm{Ia}^{+}, \mathrm{HTA}-1^{+}$cell types constitute only a small proportion $(5-20 \%)$ of the dermal $\mathrm{Ia}^{+}$ (HTA-1 ${ }^{-}$) populations. ${ }^{10} 20$

In contrast to the skin, the lymph node showed a more heterogeneous infiltrate. Again, there were numerous $\mathrm{Ia}^{+}$, HTA-1 ${ }^{+}$cells throughout the tissue which is an uncommon finding in normal or stimulated lymph nodes. Likewise, lymph nodes from patients with MF or Sézary syndrome contain less than $10-15 \%$ of $\mathrm{Ia}^{+}, \mathrm{HTA}-1^{+}$cell types within the cleate giant cells, often described in H-X lesions, ${ }^{17} 2122$ $\mathrm{Ia}^{+}$non-lymphoid population. The bizarre multinuwere $\mathrm{Ia}^{-}$, HTA-1-. Only a weak expression of Ia-like antigen was observed in the peripheral cytoplasm of some giant cells. Characteristically, the nodal infiltrates in $\mathrm{H}$-X efface the normal architecture and are accompanied by a variety of normal cell types. 2122 Although typical eosinophil granulomas were not present in this lymph node, numerous plasma cells and moderate numbers of eosinophils were observed. Residual areas of $\mathbf{B}$ lymphocytes maintained the same phenotype $\left(\mathrm{Ia}^{+}, \mathrm{IgM}^{+}, \mathrm{IgD}^{+}\right.$, mixed $\kappa^{+}, \lambda^{+}$light chains) as immunocompetent $\mathrm{B}$ cells in primary nodules and follicle mantles of normal lymphoid tissue. ${ }^{23}$ There was, however, a striking lack of HuTLA ${ }^{+} \mathrm{T}$ cells.

The second feature of this study is the demonstration that IF reagents can be successfully combined with ACPase enzyme histochemistry on frozen tissue sections without loss of reactivity in either system. Using these techniques separately on adjacent tissue sections, the enzyme reactions and immunological findings were strikingly variable in both skin and lymph node biopsies. However, these features could be closely related to each other using the combined IF and histochemical technology. Demonstration of $\mathrm{Ia}^{+}, \mathrm{HTA}-1^{+}$cells in the skin with weak ACPase and ANAE activity but moderate amounts of ATPase supports previous histochemical studies. ${ }^{5}{ }^{24}$ Similarly in the lymph node, the $\mathrm{Ia}^{+}, \mathrm{HTA}-1^{+}$cells were unreactive or weakly reactive for ACPase, ATPase and ANAE. In contrast, the multinucleate giant cells were Ia-, HTA-1- but were strikingly ACPase ${ }^{+}$ and showed variable amounts of ANAE and ATPase. Other minor cell populations including $\mathrm{Ia}^{+}, \mathrm{HTA}-1^{-}$, $\mathrm{ACPase}^{+}$(type II) irregular cells and small numbers of $\mathrm{Ia}^{+}, \mathrm{HTA}_{-1}^{-}$, $\mathrm{ACPase}^{+}$round cells were similar to interdigitating reticulum cells and tissue macrophages. These various immunological and enzyme patterns more clearly define the heterogeneous nature of the cells involved in H-X. It is not known whether the predominating $\mathrm{Ia}^{+}, \mathrm{HTA}-1^{+}, \mathrm{ACPase}^{-}$ cells and the other cell types including $\mathrm{Ia}^{-}, \mathrm{HTA}-\mathrm{1}^{-}$, $\mathrm{ACPase}^{+}$giant cells are derived from the same cell lineage or whether the latter cell type represents a reactive element stimulated by the aberrant $\mathrm{Ia}^{+}$, HTA-1+ population.

The phenotypic similarity between $\mathrm{Ia}^{+}, \mathrm{HTA}-1^{+}$ $\mathrm{H}-\mathrm{X}$ cells and normal $\mathrm{Ia}^{+}, \mathrm{HTA}-1^{+} \mathrm{LC}$ confirms previous observations that $\mathrm{H}-\mathrm{X}$ cells contain ultrastructural bodies which are indistinguishable from the Birbeck granules in LC. ${ }^{3}$ These findings support the concept that $\mathrm{H}-\mathrm{X}$ represents an abnormal proliferation of LC. ${ }^{25}$ There is much evidence to show that normal epidermal LC function as specialised immunological accessory cells to initiate immune responses in allergen-stimulated states. ${ }^{26}$ These bone marrow-derived cells ${ }^{27}$ are capable of trapping antigen and migrating through dermal lymphatics to regional lymph nodes to present antigen to effector $\mathrm{T}$ cells. ${ }^{28} \mathrm{LC}$ also resembles a variety of other $\mathrm{Ia}^{+}$bone marrow derived macrophages including interdigitating reticulum cells (IDR) in T-dependent areas of peripheral lymphoid tissue ${ }^{28}$ and "veiled" cells of the dermal afferent lymphatics. ${ }^{29}$ Clearly a spectrum of these types as well as tissue macrophages are involved in $\mathrm{H}-\mathrm{X}$ lesions.

It was not surprising to find that only scanty numbers of $T$ lymphocytes were present in the skin and lymph node lesions. Immunological abnormalities such as combined immunodeficiency and 
impaired cell mediated immune responses have been associated in some cases of H-X. ${ }^{30}$ Recently, abnormal immune function has been demonstrated in a series of $\mathrm{H}-\mathrm{X}$ patients who lacked $\mathrm{T}$ cell $\mathrm{H}_{2}$ receptors. ${ }^{31}$ In normal tonsil, inducer $\mathrm{T}$ cells $\left(\mathrm{OKT} 4^{+}\right.$, $\mathrm{OKT}^{-}$) form close contact with $\mathrm{Ia}^{+}$IDR cells. ${ }^{13}$ Similar $\mathrm{T}$ cell-Ia ${ }^{+}$cell contacts are demonstrated in MF where Ia-like antigens are strongly expressed on the proliferating non-lymphoid elements. ${ }^{10}$ Despite increased numbers of $\mathrm{Ia}^{+}$cells in $\mathrm{H}-\mathrm{X}$ lesions, the lack of $\mathrm{T}$ cells suggest either a loss of normal $\mathrm{T}$ lymphocyte control or a reactive local $\mathrm{T}$ cell deficiency. It will be interesting to see if the reported beneficial effects of thymic hormonal extracts ${ }^{31}$ show any influence on the $T$ cell deficiency in the lesions.

It is clear from this study that the $\mathrm{Ia}^{+}, \mathrm{HTA}-1^{+}$cells in $\mathbf{H}-\mathbf{X}$ express the usual immunohistochemical characteristics of $\mathrm{Ia}^{+}, \mathrm{HTA}-1^{+} \mathrm{LC}$ but have abnormal migratory patterns in the skin, lymph node ${ }^{21}$ and bone marrow (unpublished observations). The reduction of intracellular enzymes, particularly ACPase, suggests that these cells are non-functional types derived from the LC lineage. In addition the aberrant features of these cells might be influenced by the $\mathrm{T}$ lymphoid system.

JA Thomas is supported by MRC grant No G/978/443. J Pritchard is supported by the Leukaemia Research Fund.

\section{References}

${ }^{1}$ Lichtenstein L. Integration of eosinophilic granuloma of bone "Letterer Siwe disease" and "Schüller-Christian disease" as related manifestations of a single nosological entity. Arch Pathol 1953;56:84-102.

${ }^{2}$ Birbeck MS, Breathnach AS, Everall JD. An electronmicroscopic study of basal melanocytes and high level clear cells (Langerhans' cells) in vitiligo.J Invest Dermatol $1961 ; 37: 51-63$.

${ }^{3}$ Basset F, Turiaf J. Identification par la microscopie ślectronique de particules de nature probablement virale dans les lesions granulomateuses d'une histiocytose X pulmonaire. C R Acad Sci (Paris) 1965;261:3701-3.

${ }^{4}$ Berman B, France DS. Histochemical analysis of Langerhans' cells. Am J Dermatopathol 1979;1:215-21.

${ }^{5}$ Elema JD, Poppema S. Infantile histiocytosis X (LettererSiwe disease). Investigations with enzyme histochemical and sheep-erythrocyte rosetting techniques. Cancer 1978; 42:555-65.

- Jaubert F, Barbey S, Nogues C, Monnet JP, Grun M, Nezelof $C$. Histiocyte $X$ positivity for non-specific esterase. J Histochem Cytochem 1980;28:45-6.

'Stingl G, Wolff-Schreiner ECH, Pichler WJ, Gschnait F, Knapp W, Wolff K. Epidermal Langerhans' cells bear Fc and C3 receptors. Nature 1977;268:245-6.

${ }^{8}$ Rowden G, Lewis MG, Sullivan AK. Ia antigen expression on human epidermal Langerhans' cells. Nature 1977;268: 247-8.

9 McMichael AJ, Pilch JR, Galfre G, Mason DY, Fabre JW, Milstein C. A human thymocyte antigen defined by a hybrid myeloma monoclonal antibody. Eur J Immunol
1979;9:520-10

${ }^{10}$ Thomas JA, Janossy G, Graham-Brown RAC, Kung PC, Goldstein $G$. The relation between $T$ cell subsets and Ia-like antigen positive non-lymphoid cells in early stages of cutaneous $\mathrm{T}$ cell lymphoma (mycosis fungoides) $J$ Invest Dermatol 1982;78:(in press).

${ }^{11}$ Fithian E, Kung PC, Goldstein G, et al. Reactivity of Langerhans' cells with hybridoma antibody. Proc Natl Acad Sci USA 1981 ;78:2541-4.

12 Janossy G, Thomas JA, Pizzolo G, et al. Immunohistological diagnosis of lymphoproliferative diseases by selected combinations of antisera and monoclonal antibodies. Br J Cancer 1980;42:1-20.

13 Janossy G, Tidman N, Selby WS, Thomas JA, Granger SM. Human T lymphocytes of inducer and suppressor type occupy different microenvironments. Nature 1980; 287:81-4.

14 Janossy G, Thomas JA, Bollum F, et al. The human thymic microenvironment: an immunohistologic study. $J$ Immunol 1980;125:202-12.

${ }^{15}$ Chilosi M, Pizzolo G, Menestrina F, et al. Enzyme histochemistry on normal and pathological paraffin embedded lymphoid tissues. Am J Clin Pathol 1981 ;76:(in press).

${ }^{16}$ Lojda Z, Gossrau R, Schiebler TH. Enzyme histochemistry: a laboratory manual. Berlin, New York: SpringerVerlag, 1979.

${ }^{17}$ Gianotti F, Caputo R. Skin ultrastructure in HandSchüller-Christian disease: report on abnormal Langerhans' cells. Arch Dermatol 1969;100:342-9.

18 Wolf HH. Subtle clues to diagnosis of skin diseases by electron microscopy: Langerhans' cell granules in histiocytosis X. Am J Dermatopathol 1979;1:77-81.

19 Rowden G, Phillips TM, Lewis MG, Wilkinson RK. Target role of Langerhans' cells in mycosis fungoides. Transmission and immunoelectron microscopic studies. J Cutan Pathol 1979;6:364-82.

${ }^{20}$ Lampert IA, Janossy G, Suitters AJ, et al. Immunological analysis of graft versus host disease in skin. Lancet 1981; ii:1352.

${ }^{21}$ Williams JW, Dorfman RF. Lymphadenopathy as the initial manifestation of histiocytosis X. Am J Surg Pathol 1979;3:405-21.

${ }^{22}$ Imamura M, Muroya K. Lymph node ultrastructure in Hand-Schüller-Christian disease. Cancer 1971;27:95664.

${ }^{23}$ Halper JP, Knowles DM, Wang CY. Ia antigen expression by malignant lymphomas: correlation with coventional lymphoid markers. Blood 1980;55:373-82.

${ }^{24}$ Leder LD. Subtle clues to diagnosis by histochemistry. Histiocytosis X. Am J Dermatopathol 1979;1:365-9.

${ }^{25}$ Nezelof C, Basset F, Rousseau MF. Histiocytosis X. Histogenic arguments for a Langerhans' cell origin. Biomedicine 1973;3:259-79.

${ }^{26}$ Silberg-Sinakin I, Baer RL, Thorbecke GJ. Langerhans cells: A review of their nature and emphasis on their immunologic functions. Prog Allergy 1978;24:128-35.

${ }^{27}$ Katz SI, Tamaki K, Sachs DH. Epidermal Langerhans' cells are derived from cells originating in the bone marrow. Nature 1979;282:324-6.

${ }^{28}$ Thorbecke GJ, Silberg-Sinakin I, Flotte TJ. Langerhans' cells as macrophages in skin and lymphoid organs. $J$ Invest Dermatol 1980;75:32-43.

${ }^{29}$ Kelly RM, Balfour BM, Armstrong JA, Griffiths S. Functional anatomy of lymph nodes. II. Peripheral lymph-borne mononuclear cells. Anat Rec 1978;190:5-21.

${ }^{30}$ Nesbit ME, O'Leary M, Dehner LP, Ramsay NKC. The immune system and the histiocytosis syndromes. $\mathrm{Am} \mathrm{J}$ Pediatr Oncol 1981;3:141-50.

${ }^{31}$ Osband ME, Lipton MJ, Lavin P, et al. Histiocytosis X. 
Demonstration of abnormal immunity, $\mathrm{T}$ cell histamine receptor deficiency, and successful treatment with thymic extract. $N$ Engl J Med 1981 ;304:146-53.
Requests for reprints to: Dr JA Thomas, Department of Histopathology, Royal Marsden Hospital, Sutton, Surrey, England.

\section{The February 1982 Issue}

\section{THE FEBRUARY 1982 ISSUE CONTAINS THE FOLLOWING PAPERS}

Quantitative bone histology in 38 patients with advanced renal failure JB EASTWOOD

Quantitative analysis of non-Hodgkin's lymphoma CEDRIC R ABBOTT, ROBERT W BLEWITT, COLIN C BIRD

Detection of surface immunoglobulins of human lymphoid cells: a comparative study of live and fixed cells using a direct immunoperoxidase procedure GUY LAURENT, MARIE FRANÇOISE GOURDIN, FELIX REYES

Immunological study of human lungs by immunoperoxidase technique BERNARD FOX, SAMI SHOUSHA, KEITH R JAMES, GILLIAN C MILLER

Practical use of a word processor in a histopathology laboratory JAMES C BRIGGS, NASSIF BN IBRAHIM, IAN MACKINTOSH, DAVID NORRIS

Macrophage origin of Reed-Sternberg cells: an immunohistochemical study SV PAYNE, DH WRIGHT, KJM JONES, MA JUDD

Lysosomal localisation of parallel tubular arrays in chronic lymphocytic leukaemia of $\mathrm{T}$ cell origin: an ultrastructural cytochemical study FRÉDÉRIQUE CAPRON, JEAN ,YVES PERROT, CLAUDE BOUCHEIX, MICHEL REYNES, VIVIANE TRICOTTET-PACZYNSKI, ALAIN BERNADOU, JAQUES DIEBOLD

Iron granules in plasma cells MARGARET $\mathrm{K}$ COOK, MICHAEL MADDEN

Granulocyte chemotaxis: multiple assay screening using a raft technique U JAYASWAL, $S$ ROPER, S ROATH

Bone marrow processing and cryopreservation DC LINCH, LJ KNOTT, KG PATTERSON, DA COWAN, PG HARPER

Cell structure and percent viability by a slide centrifuge technique MARGARET G FITZGERALD, CS HOSKING

Ascorbate status and fibrinogen concentrations after cerebrovascular accident $R$ HUME, BD VALLANCE, MM MUIR
Circulating CK-MB and CK-BB isoenzymes after gastrointestinal surgery SWEI $H$ TSUNG

Total CK activity and isoenzyme patterns in normal and neoplastic tissue of gastrointestinal tract SWEI H TSUNG

Serum glutamate dehydrogenase is not a reliable marker of liver cell necrosis in alcoholics WJ JENKINS, SB ROSALKI, Y FOO, PJ SCHEUER, E NEMESANSZKY, S SHERLOCK

Diagnosis of Legionella pneumophila infections by means of formalised yolk sac antigens TG HARRISON, AG TAYLOR

Failure of the fluorescent antibody reaction to identify penicillinase-producing gonococci SHEENA A WAITKINS, R DAWN ANDERSON

Osteomyelitis and septic arthritis caused by Kingella Kingae JM DAVIS, MM PEEL

Swabs and swab-transport media kits in the isolation of upper respiratory bacteria PW ROSs, CG CUMMING, H LOUGH

Comparative study of three tests (dye test, indirect haemagglutination test, latex agglutination test) for the detection of antibodies to Toxoplasma gondii in human sera ALAN H BALFOUR, DG FLECK, HUW PA HUGHES, D SHARP

Appraisal of Anotox, a new anerobic atmospheric detoxifying agent for use in anaerobic cabinets JS BRAZIER

\section{Technical methods}

Tissue carbohydrate identification by the use of lectins KP WEST, HA PLATTS, A FLETCHER, F WALKER A method for transmission and scanning electron microscopy of undecalcified human bone marrow biopsy specimens using cryofracture $F$ KUTO, T NAGAOKA, M HAYASHI, Y HIRASAWA, $\mathrm{H}$ TOKUHIRO

\section{Letters to the Editor}

Book Reviews

Copies are still available and may be obtained from the PUBLISHING MANAGER, BRITISH MEDICAL ASSOCIATION, TAVISTOCK SQUARE, LONDON WC1H 9JR, price $£ 5.00$, including postage 